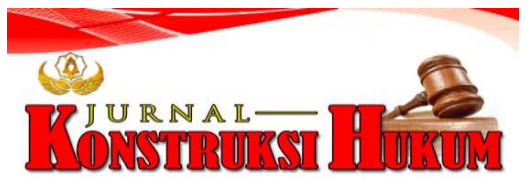

\title{
EFEKTIVITAS PERATURAN DAERAH KABUPATEN KLUNGKUNG NO.7 TAHUN 2014 TENTANG PENGELOLAAN SAMPAH
}

\author{
I Kadek Wisnu Dwipayana Ariska, I Ketut Sukadana, Diah Gayatri Sudibya \\ Fakultas HukumUniversitas Warmadewa, Denpasar-Bali, Indonesia
}

\begin{abstract}
Abstrak
Salah satu kota di Provinsi Bali, Kabupaten Klungkung; merupakan salah satu kabupaten di bali yang sangat berkembang dalam kesenian dan industry kecil, akan tetapi memiliki masalah yaitu sampah. Penelitian ini bertujuan untuk menganalisis proses pelaksanaan dan menganalisis tindakan pemerintah peraturan daerah Kabupaten Klungkung No 7 Tahun 2014 pada masyarakat Kabupaten Klungkung. Metode penelitian yang digunakan adalah penelitian empiris. Dalam melaksankan penelitian ini, peneliti turun langsung ke lapangan dan meneliti langsung apa yang terjadi di lapangan yang sebenarnya. Hasil penelitian menunjukan bahwa pemerintah yang memiliki kekuasaan penuh tentang pengeloaan sampah harus mengayomi masyarakat agar dapat di kelola sampah tersebut dengan baik dan benar, bukan membuang sampah sembarang. Melalui penelitian ini diharapkan kepada Pemerintah kabupaten klungkung untuk meningkatkan partisipasi masyarakat dalam pengelolaan sampah dengan baik dan benar.
\end{abstract}

Kata kunci: Peraturan daerah, pengelolaan sampah, Perda kabupaten klungkung

\begin{abstract}
One of the cities in Bali Province, Klungkung Regency; is one of the districts in Bali which is very developed in the arts and small industry, but has a problem, namely waste. This study aims to analyze the implementation process and analyze the actions of the local government regulations of Klungkung Regency No. 7/2014 on the people of Klungkung Regency. The research method used is empirical research. In carrying out this research, researchers went directly to the field and directly examined what was happening in the real field. The results showed that the government, which has full authority on waste management, must protect the community so that it can be managed properly and properly, not littering. Through this research, it is hoped that the Klungkung Regency Government will increase community participation in proper and correct waste management.
\end{abstract}

Keywords: local regulations, waste management, Klungkung regency Perda

\section{PENDAHULUAN}

Faktor kerusakan lingkungan yang terjadi di lingkungan masyarakat adalah sebuah kesalahan masyarakat dalam hal membuang sampah (Hardjasoemantri, 1999). Sering kali terjadi di kehidupan sehari-hari banyak masyarakat yang membuang sampah sembarang, sehingga mengakibatkan kerusakan lingkungan. Banyak kasus ini terjadi di mana-mana yang membuang sampah sembarang, padahal sampah sangatlah bermanfaat jika di kelola dengan baik (Gunawan, 2007). Sampah tidak hanya menghasilkan uang jika di kelola dengan baik, namun lingkungan juga akan bersih. Tentunya, yang menerima manfaat ini adalah masyarakat itu sendiri.

Sampah sebutulnya harus di manfaatkan dengan baik dan di kelola supaya sampah bisa menjadi bahan yang berguna di kalangan masyarakat, janganlah kita membuang sampah sembarang bisa merusak lingkungan, kita harus menjaga lingkungan dengan baik agar bisa hidup di dalam kehidupan sehari-hari dengan sehat terhindar dari lingkungan yang kotor dan banyak dengan sampah, sangat di sayangkan semakin parah kerusakan lingkungan ada beberapa masyarakat yang membuang sampah sembarang yang mengakibatkan kerusakan lingkungan.

Salah satu kota di Provinsi Bali, Kabupaten Klungkung; merupakan salah satu kabupaten di bali yang sangat berkembang dalam kesenian dan industry kecil, akan tetapi memiliki masalah yang sama dengan daerah lainnya yaitu sampah. Banyak dari masyarakat di Kabupaten Klungkung yang tidak menyadari bahwa sampah bisa di kelola dengan baik dan dapat di jadikan alat untuk kebutuhan seharihari. Ketidaktahuan masyarkat dalam mengelola sampah disebabkan kurangnya sosialisai. Oleh karena itu, perlu adanya sosialisasi terhadap masyarakat tentang pengelolaan sampah yang baik agar masyarakat bisa mengelola sampah dengan sendiri dan membuat alat yang bermanfaat bagi kehidupan 
sehari-hari mereka maka dari masyarakat harus berbenah diri dari sekarang mengenai sampah agar bisa di kelola dengan baik, bukan di buang dan di biarkan begitu saja. Selain sampah plastik yang sangat begitu banyak berserakan di pinggir jalan Kabupaten Klungkung masih ada juga sampah yang sisa dari persembahyangan di pasar dan sebagainya. Banyaknya sampah di sekitar lingkungan atau membuang sampah sembarang bisa mengakibatkan kerusakan lingkungan dan ekosistem tanaman bisa juga tersurut air sungai yang bisa mengakibatkan banjir yang merugikan masyarakat sendiri, sangat di sayangkan sebuah sampah yang kita anggap sepele bisa mengakibatkan banyak kerusakan di dalam lingkungan kehidupan kita sehari-hari maka dari itu perlu di adakan penanganan sampah yang baik yang di berikan oleh pemerintah agar masyarakat bisa mengelola sampah dengan baik juga bisa membuat sampah tersebut menjadi alat yang bermanfaat bagi kehidupan sehari-hari dan bisa dibuat kelompok agar bisa mengelola sampah secara sama-sama sehingga hasil tersebut bisa di jual dan hasilnya bisa di bagi bersama, sampah juga bisa di buat kerajinan yang sangat bagus di rumah masingmasing, maka dari itu kita harus kelola sampah dengan baik bukan membuangnya dengan sembarang.

Sebagai Negara hukum yang artinya Indonesia di dalam kehidupan bermasyarakat pasti tunduk dalam sebuah peraturan hukum yang di buat oleh pemerintah. Menurut, (Ranadireksa, 2007) bahwa suatu negara hukum akan membuat keadilan yang baik buat masyarakat kecil dan baik juga pejabat, bukan dengan memihak kepada yang beruang. Sistem hukum sebagai bentuk untuk mendapatkan keadilan bukan dengan cara mendapatkan keuntungan diri sendiri.

Efektivitas suatu peraturan di kabupaten kota yang merupakan peraturan yang harus di jalankan di dalam kehidupan masyarakat adalah sebuah fakta dasar yang memberi pengertian tentang mengelola sampah dengan baik dan benar yaitu dengan mengelola dengan baik dan benar bisa menjadi pedoman bagi masyarakat agar bisa mematuhi peraturan dengan baik, sehingga masyarakat bisa menjalankan kehidupan sesuai dengan aturan dan norma yang berlaku supaya masyarakat bisa hidup dengan baik di lingkungannya masing-masing tanpa harus menggangu orang lain (Apriadi, 1998). Dengan membuang sampah sembarangan dapat membuat orang lain terganggu, apalagi membuang sampah sembarang di lingkungan tempat tinggal mereka. Selain itu, juga sampah bisa membuat kerusakan lingkungan dan menyebabkan banjir yang merugikan diri sendiri dan orang lain.

Dengan demikian, sampah haruslah kita kelola dengan baik agar lingkungan kehidupan kita bersih dan nyaman dan jauh dari bencana alam sperti kerusakan lingkungan, banjir yang dapat menyebabkan longsor, merusak ekosistem hewan baik di darat mapun di air. Sampah adalah sisa-sisa bahan yang mengalami perlakuan baik karena bisa di ambil dan di daur ulang dan bisa juga menjadi suatu kerajinan yang bisa mengahasilkan uang agar menambah kebutuhan ekonomi di kehidupan sehari-hari, sampah kita harus buat kembali dengan baik dan di daur lagi, bukan di buang sembarang yang mengakibatkan kerusakan lingkungan, di tempat-tempat wisata banyak sekali sampah yang berserakan banyak dari masyarakat luar yang membuang sampah di tempat wisata, maka dari itu kita sebagai masyarakat yang baik kita harus mengingatkan sesama kita agar jangan membuang sampah sembarang.

Beberapa penelitian yang relevan dengan penelitian saat ini, diantaranya mengenai Efektivitas Peraturan Daerah Provinsi Bali Nomor 5 Tahun 2011 Tentang Pengelolaan Sampah dalam Melindungi Masyarakat terhadap Dampak Bau Penanganan Sampah Di TPA Pesanggaran (Dewi \& Utama, 2018), selanjutnya mengenai penerapan peraturan daerah kabupaten klungkung no. 7 tahun 2014 tentang pengelolaan sampah di Kabupaten Klungkung (Pariasa, Suardita, \& Satyawati, 2016), dan terakhir mengenai efektivitas penanganan masalah sampah berbasis masyarakat di desa tangkas sebagai penerapan peraturan daerah kabupaten klungkung no. 7 tahun 2014 tentang pengelolaan sampah (Yogi \& Dunia, 2018).

Sehubungan dengan pembahasan di atas, penelitian ini didesain untuk menganalisis proses pelaksanaan peraturan daerah Kabupaten Klungkung No 7 Tahun 2014 pada masyarakat Kabupaten Klungkung dan menganalisis tindakan pemerintah Kabupaten Klungkung terhadap pelanggaran Peraturan daerah Kabupaten Klungkung No 7 Tahun 2014, pada masyarakat Kabupaten Klungkung.

\section{METODE PENELITIAN}

Jenis penelitian yang di gunakan adalah tipe penelitian empiris (Soekanto \& Mamudji, 2018). Dalam melaksankan penelitian ini, peneliti turun langsung ke lapangan dan meneliti langsung apa yang terjadi di lapangan yang sebenarnya. Penelitian empiris ini adalah sebuah penelitian yang tidak tertulis atau identifikasinya tidak tertulis, dari pendekatan masalah di mampukan agar mengetahui bagaimana 
masyarakat bisa mengelola sampah dengan baik atau membuat suatu kerajinan sampah dengan baik supaya bisa di kembangkan sampah tersebut menjadi hal yang bermanfaat bagi masyarakat, bukan di buang sampah tersebut yang mengakibatkan kerusakan lingkungan.

Sumber data ini mengkaji dari perumusan masalah yang di paparkan di atas, sebagai sumber data yang akan di gunakan adalah 1) Data primer ini mengacu pada informan dan informasi yang berlaku di mana sumber data ini digunakan untuk memberikan suatu informasi terhadap subjek penelitian, dan bisa memberi manfaat bagi orang lain yaitu masyarakat dan pemerintah. 2) Data sekunder ini berasal dari sebuah bacaan yang sangat relevan dan mengacu pada kajian hukum yang berlaku saat ini dengan tujuan yang bermanfaat bagi masyarakat dan pemerintah (Marzuki, 2011).

Teknik pengumpulan data ini menggunakan data primer yang akan di kumpulkan dengan menggunakan teknik observasi yang membuat suatu pengertian tentang gelaja observasi tentang pengelolaan sampah yang baik agar di manfaatkan oleh masyarakat dengan baik dan bisa memenuhi kebutuhan sehari-hari bagi masyarakat, Teknik wawancara teknik ini menggunakan Tanya jawab antar subjek dan objek mengenai tentang pengelolaan sampah di kabupaten klungkung, agar masyarakat dapat kelola sampah dengan baik bisa membuat kerajinan yang bisa menghasilkan uang bagi masyarakat, dan bisa memenuhi kebutuhan ekonomi masyarakat, dengan ini masyarakat tidak lagi membuang sampah sembarang, mereka bisa menyimpan atau mengumpul sampah tersebut agar di kelola dengan baik oleh masyarakat sendiri

\section{HASIL DAN PEMBAHASAN}

\section{Penerapan Pemerintah dalam Pelaksanaan Pengelolaan Sampah di Kabupaten Klungkung}

Kewenangan pengelolaan sampah adalah kewenangan yang di lakukan oleh pemerintah yang membuat tanggung jawab yang di berikan oleh orang lain untuk di kelola dengan baik (Jalil, 2019), tapi nyatanya sekarang banyak sampah yang berserakan di mana-mana terkhususnya di kabupaten klungkung, pemerintah yang memeliki tanggung jawab untuk mengelola sampah dengan baik bukan di biarkan begitu saja sehingga masyarakat membuang sampah sembarang yang mengakibatkan kerusakan lingkungan dan menyebabkan banjir, yang ujung-ujungnya pemerintah yang di salahkan, maka dari itu pemerintah harus memberi sosialisasi tentang pengelolaan sampah yang baik di kalangan masyarakat agar masyarakat tahu mengelola sampah dengan baik, dan tidak membuang sampah dengan sembarang, yang menyebabkan banjir dan kerusakan lingkungan. Menurut (Soekanto, 2008) dalam pembuangan sampah sembarang di tentukan oleh peraturan yang di buat oleh pemerintah untuk memberi sanksi kepada masyarakat yang membuang sampah sembarang yang bisa menyebabkan kerusakan lingkungan dan banjir, dalam menjalakan peraturan daerah di kabupaten klungkung tentang pengelolaan sampah sebagai limbah dan sampah yang berserakan harus di bersihkan dengan baik agar tidak membuat masyarakat merasa di rugikan harus ada dari masyarakat yang memberikan sosialisasi tentang pengelolaan sampah dengan baik agar masyarakat bisa mengetahui bagaimana cara mengelola sampah dengan baik dan baik benar supaya mereka tidak lagi membuang sampah sembarang.

Dalam penerapan pelaksanaan pemerintah dalam mengelola sampah dengan baik dan benar perlu melakukan kerjasama dengan pemerintah dan masyarakat agar bisa mengatasi kasus-kasus pembuangan sampah sembarang supaya dapat menjaga lingkungan di Kabupaten Klungkung yang bersih dan nyaman untuk bisa di tinggal dengan baik dan tidak terjadi keresahan di tengah masyarakat dengan pembuangan sampah sembarang dengan pelaksanaan penerapan peraturan daerah di Kabupaten klungkung tentang pembuangan sampah sembarang, di mampukan menyadarkan masyarakat agar bisa tertib membuang sampah dengan baik bukan dengan membuang sampah dengan sembarang yang mengakibatkan kerusakan lingkungan dan banjir yang bisa merugikan masyarakat dan kerusakan lingkungan, maka dari itu sebagai masyarakat yang baik di mampukan untuk membuang sampah dengan baik dan benar supaya lingkungan terjaga dan aman dari sampah yang berserakan di lingkungan masyarakat, supaya masyarakat bisa hidup dengan baik dan nyaman.

\section{Upaya yang Dilakukan oleh Pemerintah Kabupaten Klungkung mengenai Pelanggaran Peraturan Daerah}

Pencemaran lingkungan sering kali terjadi di kabupaten klungkung yaitu pembuangan sampah sembarang yang mengakibatkan pencemaran lingkungan dan kerusakan lingkungan, dalam upaya penegakan hukum mengenai pembuangan sampah sembarang yang harus di lakukan oleh pemerintah 
adalah membuat peraturan yang membuat efek jera bagi masyarakat yang membuang sampah sembarang agar perbuatan mereka tidak di ulangi lagi supaya tidak ada lagi yang membuang sampah dengan sembarangan yang membuat kecemaran lingkungan.

Sampah menurut asal zat yang dikandungnya, secara garis besar sampah dibagi menjadi 2 kelompok yaitu sampah organik dan sampah anorganik (Umami, 2017). Sosialisasi mengenai tentang pengelolaan sampah baik organik maupun anorganik dengan baik dan benar yang di lakukan secara efektif adalah turun langsung ke lapangan dan memberikan materi tentang pengelolaan sampah yang baik dan benar terhadap masyarakat agar masyarakat tahu mengelola sampah dengan baik dan benar dengan adanya pemahaman tersebut maka masyarakat bisa mengurangi pembuangan sampah sembarang, maka dari itu perlu upaya dari pemerintah yang signifikan buat masyarakat dalam mengelola sampah dengan baik dan benar.

Pemerintah Kabupaten Klungkung berhak membuat peraturan bagi masyarakat yang membuang sampah sembarang, dengan ada peraturan tersebut bisa memberi efek jera bagi masyarakat yang membuang sampah sembarang yang bisa merusak lingkungan dan menyebabkan banjir.

\section{SIMPULAN}

Berdasarkan sesuai dengan penelitian di atas maka peneliti mengambil kesimpulan yaitu, pemerintah yang memiliki kekuasaan penuh tentang pengeloaan sampah harus mengayomi masyarakat agar dapat di kelola sampah tersebut dengan baik dan benar, bukan membuang sampah sembarang. Melalui penelitian ini diharapkan kepada Pemerintah kabupaten klungkung untuk meningkatkan partisipasi masyarakat dalam pengelolaan sampah dengan baik dan benar

\section{DAFTAR PUSTAKA}

Apriadi. (1998). Menghindari, Mencegah, dan Menyingkarkan Sampah. Jakarta: Abdi.

Dewi, L. P. N., \& Utama, I. M. A. (2018). Efektivitas Peraturan Daerah Provinsi Bali Nomor 5 Tahun 2011 Tentang Pengelolaan Sampah Dalam Melindungi Masyarakat Terhadap Dampak Bau Penanganan Sampah Di TPA Pesanggaran. Kertha Negara: Journal Ilmu Hukum, 6(4).

Gunawan, G. (2007). Mengelolah Sampah Jadi Uang. Jakarta: Transmedia Pustaka.

Hardjasoemantri, K. (1999). Hukum Lingkungan. Jakarta: Sinar Grafika.

Jalil, A. (2019). Efektifitas pengolahan Sampah di Pulau Kodingareng Kecamatan Sangkarrang Kota Makassar. Universitas Islam Negeri Alauddin Makassar.

Marzuki, P. M. (2011). Penelitian Hukum. Jakarta: Kencana Prenida Media.

Pariasa, I. M. P., Suardita, I. K., \& Satyawati, N. G. A. D. (2016). Penerapan Peraturan Daerah Kabupaten Klungkung No. 7 Tahun 2014 tentang Pengelolaan Sampah Di Kabupaten Klungkung. Kertha Negara: Journal Ilmu Hukum, 4(1).

Ranadireksa, H. (2007). Arsitektur Konstitusi Demokrasi. Bandung: Focus Media.

Soekanto, S. (2008). Faktor-Faktor yang Mempengaruhi Penegakan Hukum. Jakarta: Rajawali Grafindo Persada.

Soekanto, S., \& Mamudji, S. (2018). Penelitian Hukum Normatif: Suatu Tinjauan Singkat (18th ed.). Jakarta: Rajawali Pers.

Umami, A. (2017). Efektivitas Peraturan Daerah No 08 Tahun 2015 Tentang Pengelolaan Sampah Di Kota Mero Terkait Kesadaran Masyarakat Dalam Pengembangan Bank Sampah Syariah. Seminar Nasional Penelitian Dan Pengabdian Pada Masyarakat, 7(2).

Yogi, N. M. T., \& Dunia, N. K. (2018). Efektivitas Penanganan Masalah Sampah Berbasis Masyarakat Di Desa Tangkas Sebagai Penerapan Peraturan Daerah Kabupaten Klungkung No. 7 Tahun 2014 Tentang Pengelolaan Sampah. Kertha Negara: Journal Ilmu Hukum, 6(4). 